\title{
Mycocerosic acid biomarkers for the diagnosis of tuberculosis in the Coimbra Skeletal Collection
}

\author{
Janet E. Redman ${ }^{a}$, Matthew J. Shaw ${ }^{\mathrm{a}, \mathrm{b}}$, Anthony I. Mallet ${ }^{\mathrm{c}}$, Ana Luisa Santos ${ }^{\mathrm{d}}$, Charlotte A. Roberts ${ }^{\mathrm{e}}$, \\ Angela M. Gernaey ${ }^{\mathrm{b}}$, David E. Minnikin ${ }^{\mathrm{a}, *}$

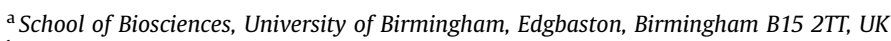 \\ ${ }^{\mathrm{b}}$ Biosciences Research Institute, University of Salford, Salford M5 4WT, UK \\ ${ }^{c}$ School of Science, Department of Life Sciences, University of Greenwich, Central Avenue, Chatham Maritime, Kent ME4 4TB, UK \\ ${ }^{\mathrm{d}}$ Departmento de Antropologia, Universidade de Coimbra, 3000-056 Coimbra, Portugal \\ ${ }^{\mathrm{e}}$ Department of Archaeology, Durham University, Durham DH1 3LE, UK
}

\section{A R T I C L E I N F O}

\section{Article history:}

Received 16 December 2008

Received in revised form

8 April 2009

Accepted 10 April 2009

\section{Keywords:}

Archaeology

Skeletons

Tuberculosis

Lipid biomarkers

Mycocerosates

\begin{abstract}
S U M M A R Y
Tuberculosis has been a scourge of humans over many millennia, but questions remain regarding its evolution and epidemiology. Fossil biomarkers, such as DNA and long-chain mycolic acids, can be detected in ancient skeletal and other materials. The phthiocerol dimycocerosate waxes are also robust biomarkers for tuberculosis and sensitive methods are available for the detection of their mycocerosic acid components. The presence of mycocerosic acids was investigated in 49 individuals from the 1837-1936 Coimbra Identified Skeletal Collection (Portugal), half with documentary data indicating tuberculosis as a cause of death. Samples were hydrolysed, acidic components converted to pentafluorobenzyl esters, the non-hydroxylated long-chain esters isolated, and this fraction separated into multimethyl-branched and other esters by normal phase high performance liquid chromatography. Negative ion chemical ionisation gas chromatography mass spectrometry was used to detect diagnostic $\mathrm{C}_{29}, \mathrm{C}_{30}$ and $\mathrm{C}_{32}$ mycocerosic acids. Mycocerosic acids were detected in archaeological material for the first time, illustrating that they are valuable biomarkers for the diagnosis of ancient tuberculosis. A 72\% correlation with the Coimbra burial record supported TB as the major cause of death. In addition, $30 \%$ of the skeletons, positive for mycocerosates, showed the presence of related long-chain mycolipenic acids. (c) 2009 Elsevier Ltd. All rights reserved.
\end{abstract}

\section{Introduction}

\subsection{Ancient tuberculosis}

It was estimated that there were 8-9 million new cases of tuberculosis (TB) and 1.6 million deaths in 2005. ${ }^{1}$ The continuing prevalence of this disease, caused by Mycobacterium tuberculosis, is partly due to the evolution of strains highly resistant to drug treatment and a higher incidence of human immunodeficiency virus (HIV) co-infection. ${ }^{1}$ Cyclical changes in TB epidemiology could underlie these recent developments, ${ }^{2,3}$ so it is important to study TB prevalence in ancient populations. By elucidating the origins and history of TB, an increase in the understanding of epidemiological patterns may develop.

Historically, the study of gross morphological change in archaeologically derived skeletal material, particularly spinal destruction has been used for TB diagnosis in ancient populations. ${ }^{4} \mathrm{~A}$ concern is

\footnotetext{
* Corresponding author. Tel.: +44(0)1214158126; fax: +44(0)1214145925.

E-mail address: d.e.minnikin@bham.ac.uk (D.E. Minnikin).
}

the non-specificity of some of these gross morphological changes, for example in rib lesions ${ }^{5,6}$ and general bone changes. ${ }^{6}$ Although TB is principally a disease of the respiratory tract, it can result in bone change in a low percentage of individuals. ${ }^{7-9}$ Unfortunately, there is uncertainty surrounding the attribution of many bone changes to $\mathrm{TB}^{10}$; other conditions, such as brucellosis and neoplasms, may cause similar alterations. ${ }^{6}$ However, a dual biomarker study ${ }^{11}$ has shown some support for macroscopic diagnostic methods, as have many aDNA studies of TB. ${ }^{12-15}$

In the last decade, ancient DNA (aDNA) analyses, using spoligotyping and sequencing techniques, have become established for characterisation of a wide range of biological samples, as exemplified by recent reports. ${ }^{12-15}$ For ancient TB diagnosis, primers that target the insertion sequence IS6110 are commonly used for identification. ${ }^{16-20}$ Ancient DNA analysis also has the potential to discriminate between different species of the Mycobacterium tuberculosis complex, such as human and bovine. ${ }^{21,22}$ However, care must be taken when using the non-specific region of IS6110, as weak cross-reactivity has been found with Mycobacterium fortuitum. ${ }^{23}$ Post-mortem oxidative and hydrolytic cleavage has also 
been shown to degrade DNA. ${ }^{24}$ To validate results from ancient microbial DNA studies, recommendations for good laboratory practice have been suggested. ${ }^{25,26}$ Finally, due to the sensitivity of amplification, inferring whether a positive result is due merely to infection or the onset of clinical TB could be difficult to determine. ${ }^{27}$

The use of chemically stable lipid biomarkers for TB diagnosis has been investigated as an alternative approach to ancient disease diagnosis. Mycobacteria produce a range of very unusual longchain lipids as components of the cell envelope, specific to the genus. $^{28}$ One such class, the mycolic acids, $C_{70}-C_{90}, 2$-alkyl, 3-hydroxy fatty acids, have been successfully detected in archaeological individuals, ${ }^{11,29,30}$ using reversed and normal phase high performance liquid chromatography (HPLC) and fluorescence detection of mycolic acids tagged with 9-chloromethylanthracene.

\subsection{The biomarker}

In this study, another class of mycobacterial lipids, the mycocerosic acids, was investigated as biomarkers for TB diagnosis in archaeological individuals. Mycocerosic acids (Figure 1) are long-chain multimethyl-branched-chain fatty acids ${ }^{28}$ which are present in representatives of M. tuberculosis, Mycobacterium bovis, Mycobacterium gastri, Mycobacterium haemophilum, Mycobacterium kansasii, Mycobacterium leprae, Mycobacterium marinum and Mycobacterium ulcerans. ${ }^{31-35}$ The mycocerosic acids of the mycobacteria are found mainly as phthiocerol dimycocerosate (PDIM) waxes or in phenolic glycolipids. ${ }^{31-35}$ Their composition can be determined by simple gas chromatography (GC), but certain types of acids have essentially the same retention times. ${ }^{36-38}$ For example, a $C_{29}$ mycocerosate with three methyl branches may overlap with a $C_{30}$ acid with four methyl branches. ${ }^{31,37,38}$ In addition, $M$. tuberculosis produces a range of other multimethyl branched fatty acids ${ }^{28,33}$ and $C_{27}$ mycolipenate (Figure 1 ) is one particularly characteristic acid that could easily be investigated along with the mycocerosates.

In pioneering studies, ${ }^{39}$ Larsson and colleagues showed that $\mathrm{C}_{32}$ mycocerosates could be detected by GC-MS in five-day cultures of tuberculosis patient sputum samples. Individual mycocerosates have been determined successfully in clinical samples by selected ion monitoring (SIM) negative ion chemical ionisation gas chromatography mass spectrometry (NI-CI GC-MS). ${ }^{36,40}$ Using SIM GC-MS improves the analytical sensitivity and simplifies biomarker detection, as only the target analytes are monitored. Chemical analysis of archaeological material for these lipids using SIM GC-MS would thus provides a robust alternative technique to corroborate diagnoses achieved by other means, such as osteological changes, ancient DNA or mycolic acid biomarkers.

It is important to be able to recognise the characteristic $M$. tuberculosis pattern of mycocerosates, typically trimethyl $\mathrm{C}_{29}$ and tetramethyl $C_{30}$ and $C_{32}{ }^{31,32,37,38,40}$ In a limited systematic study, ${ }^{31}$ it was shown that the mycocerosates of $M$. bovis had mainly $C_{26}, C_{27}, C_{29}, C_{30}$ components, lacking the major amounts of the $C_{32}$ mycocerosate

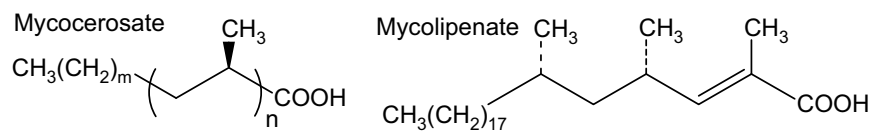

For mycocerosate components: $m=16-20, n=2-4$

$\mathbf{C}_{26}(\mathrm{~m} / \mathrm{z} 395) \mathrm{m}=18, \mathrm{n}=2 ; \mathbf{C}_{27}(\mathrm{~m} / \mathrm{z} 409) \mathrm{m}=16, \mathrm{n}=3 ; \mathbf{C}_{29}(\mathrm{~m} / \mathrm{z} 437) \mathrm{m}=$

$18, \mathrm{n}=3 ; \mathbf{C}_{30}(\mathrm{~m} / \mathrm{z} 451) \mathrm{m}=16, \mathrm{n}=4 ; \mathbf{C}_{32}(\mathrm{~m} / \mathrm{z} 479) \mathrm{m}=18, \mathrm{n}=4 ; \mathbf{C}_{33}(\mathrm{~m} / \mathrm{z}$

493) $m=16, n=5 ; C_{34}(m / z 507) m=20, n=4$.

$\mathbf{C}_{27}$ mycolipenate has $\mathrm{m} / \mathrm{z} 407$

Figure 1. Structures of $\mathrm{C}_{26}-\mathrm{C}_{34}$ mycocerosic and $\mathrm{C}_{27}$ mycolipenic acids from M. tuberculosis. Mass spectral $\mathrm{m} / \mathrm{z}$ values refer to negative ions observed on fragmentation of pentafluorobenzyl esters. typical of $M$. tuberculosis. It was later indicated ${ }^{38}$ that the attenuated BCG vaccine strain of $M$. bovis had essentially the same mycocerosate profile as that of $M$. tuberculosis. Extensive studies will be needed to determine if mycocerosic acid profiles can distinguish between infections due to $M$. bovis and M. tuberculosis but, in the present study, attention will be concentrated on the major $C_{29}, C_{30}$ and $C_{32}$ components, characteristic for the human disease. The profile for mycocerosates from $M$. leprae is distinct in having a profile with a dominant $C_{34}$ component. $^{34,38}$ There is a possibility that archaeologically derived bone samples could be contaminated with the environmental mycobacteria, M. kansasii and M. marinum. The mycocerosate profile of the former resembles that of $M$. tuberculosis, but with a minor proportion of the $C_{32}$ component; that of the latter has mainly $C_{27}$ with small proportions of $C_{29}$ and $C_{30}$. ${ }^{31,32,38}$

\subsection{The archaeological samples}

Rib samples from individuals of the 19th and 20th century Coimbra Identified Skeletal Collection were taken and analysed. This Collection, curated by the Anthropological Museum of the University of Coimbra, derives from the Cemetery of Conchada, Coimbra, Portugal. This is a small in-use cemetery that serves Coimbra University Hospital (CUH) and a variety of other sites in and around Coimbra. The collection is "identified" because the associated medical records are present for all individuals.

The collection comprises 505 individuals who died at CUH and 240 who died elsewhere; only those from CUH have been included in this study. Within the CUH component of the skeletal collection, there are 266 males and 239 females. Both adults and non-adults are represented, but most were over 21 years at death. Born between 1822 and 1921, the individuals died between 1904 and 1936, with ages at death ranging between 7 and 96 years. ${ }^{41}$ The individuals were exhumed between 1916 and 1946 and are curated at the University of Coimbra, Department of Anthropology, along with their medical records. Tuberculosis, at $25 \%$ of the total, is the commonest recorded cause of death in the Collection, followed by cardiac disease (14\%) and other respiratory diseases (13\%). The figure for TB mortality is high, but this correlates well with data from UK hospital populations from around the same period. ${ }^{42}$

\section{Materials and methods}

\subsection{Material analysed}

The representative 49 individuals, chosen from the 505 skeletons in the Coimbra Collection, ${ }^{41,42}$ were all adults ( $>15$ years old at death), who died between 1910 and 1936, with 48\% being associated with tuberculosis as a cause of death. The rib samples were crushed to a fine powder using a mortar and pestle, cleaned thoroughly between samples with dichloromethane (DCM). Disposable nitrile gloves were worn when handling sample material. Standard heat killed lyophilised cells of the standard tuberculin strain, M. tuberculosis $\mathrm{PN},{ }^{43}$ were provided by the Central Veterinary

Table 1

Elution scheme for fractionation of long-chain extracts on silica gel cartridges.

\begin{tabular}{lcccl}
\hline Fraction & Heptane & Toluene & Dichloro-methane & Vol $/ \mathrm{ml}$ \\
\hline 1 & 100 & 0 & 0 & 6 \\
2 & 97 & 3 & 0 & 6 \\
3 & 90 & 10 & 0 & 6 \\
4 & 80 & 20 & 0 & 6 \\
5 & 50 & 50 & 0 & 6 \\
6 & 0 & 100 & 0 & 6 \\
7 & 0 & 100 & 0 & 6 \\
8 & 0 & 0 & 100 & 6 \\
\hline
\end{tabular}




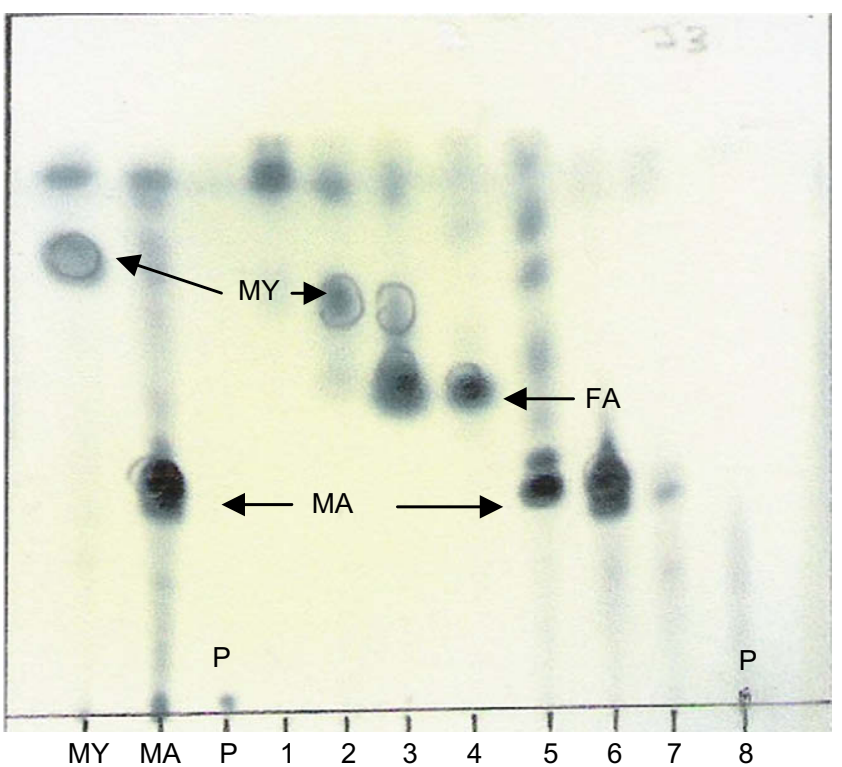

Figure 2. TLC analysis of the 8 fractions from normal phase cartridge separation of longchain compounds from $M$. tuberculosis PN, using the elution scheme detailed in Table 1. MY, mycocerosic acid PFB ester; MA, mycolic acid PFB ester; P, phthiocerol; FA, other fatty acid PFB ester. TLC developed in petrol $60-80^{\circ} \mathrm{C}$ :ethyl acetate, 9:1 and components revealed by spraying with $10 \%$ ethanolic molybdophosphoric acid and charring.

Laboratory, Weybridge, UK; M. marinum ATCC 927, M. kansasii ATCC 12478 and $M$. bovis MNC 8 were cultivated as described previously. ${ }^{31}$ Analytical grade chemicals (Sigma-Aldrich, Poole, Dorset, UK) and solvents (VWR International Ltd, Lutterworth, Leicestershire, UK) were used, unless stated otherwise.

\subsection{Hydrolysis of biomass}

Samples of bone $(\sim 1.0 \mathrm{~g})$ and standard cells $(50 \mathrm{mg})$ were hydrolysed overnight at $100^{\circ} \mathrm{C}$ in sealed $8.5 \mathrm{ml}$ Pyrex tubes, with a PTFE-lined cap, using a solution of $30 \% \mathrm{w} / \mathrm{v}$ methanolic potassium hydroxide $(2 \mathrm{ml})$ and toluene $(1 \mathrm{ml}) .{ }^{36-38}$ After cooling to room temperature, the tubes were cooled to $0{ }^{\circ} \mathrm{C}$ in an ice bath. The reaction mixtures were acidified to $\mathrm{pH} 1$ by the addition of $10 \%$ aqueous $\mathrm{HCl}(1 \mathrm{ml})$ and dropwise addition of concentrated $\mathrm{HCl}$. Long-chain compounds were extracted with diethyl ether $(3 \times 1 \mathrm{ml})$. The combined organic extracts were evaporated to dryness under a stream of $\mathrm{N}_{2}$.

\subsection{Preparation of standard pentafluorobenzyl esters}

Total long-chain fractions from standard cells were transferred to $8.5 \mathrm{ml}$ Pyrex tubes, with PTFE-lined caps. Pentafluorobenzyl (PFB) esters were prepared by tube rotator mixing, for $1 \mathrm{~h}$, with phase-transfer catalyst solution $(\mathrm{NaOH}[0.8 \mathrm{~g}]$ and tetra- $n$-butylammonium hydrogen sulfate $[3.39 \mathrm{~g}]$ in distilled water $[100 \mathrm{ml}]$ ) $(2 \mathrm{ml})$ and pentafluorobenzyl bromide [5 $\mathrm{g}]$ in dichloromethane [100 ml] $(1 \mathrm{ml}) .{ }^{44}$ The upper aqueous layer was removed and the lower organic layer was washed successively with $10 \%$ aqueous $\mathrm{HCl}$ $(1 \mathrm{ml})$ and distilled water $(1 \mathrm{ml})$. The organic layer was evaporated to dryness under $\mathrm{N}_{2}$.

The dried residues were dissolved in minimal heptane. Each solution was applied to a $500 \mathrm{mg} / 4 \mathrm{ml}$ Alltech 209250 normal phase cartridge (Alltech Associates, Carnforth, Lancashire, UK), prewashed with heptane, and the solvent was allowed to evaporate completely. An International Sorbent Technology (IST) Vacmaster FlashVac 20 vacuum tank, with a vacuum of -0.35 Torr, was used to fractionate the samples, according to the solvent elution regime
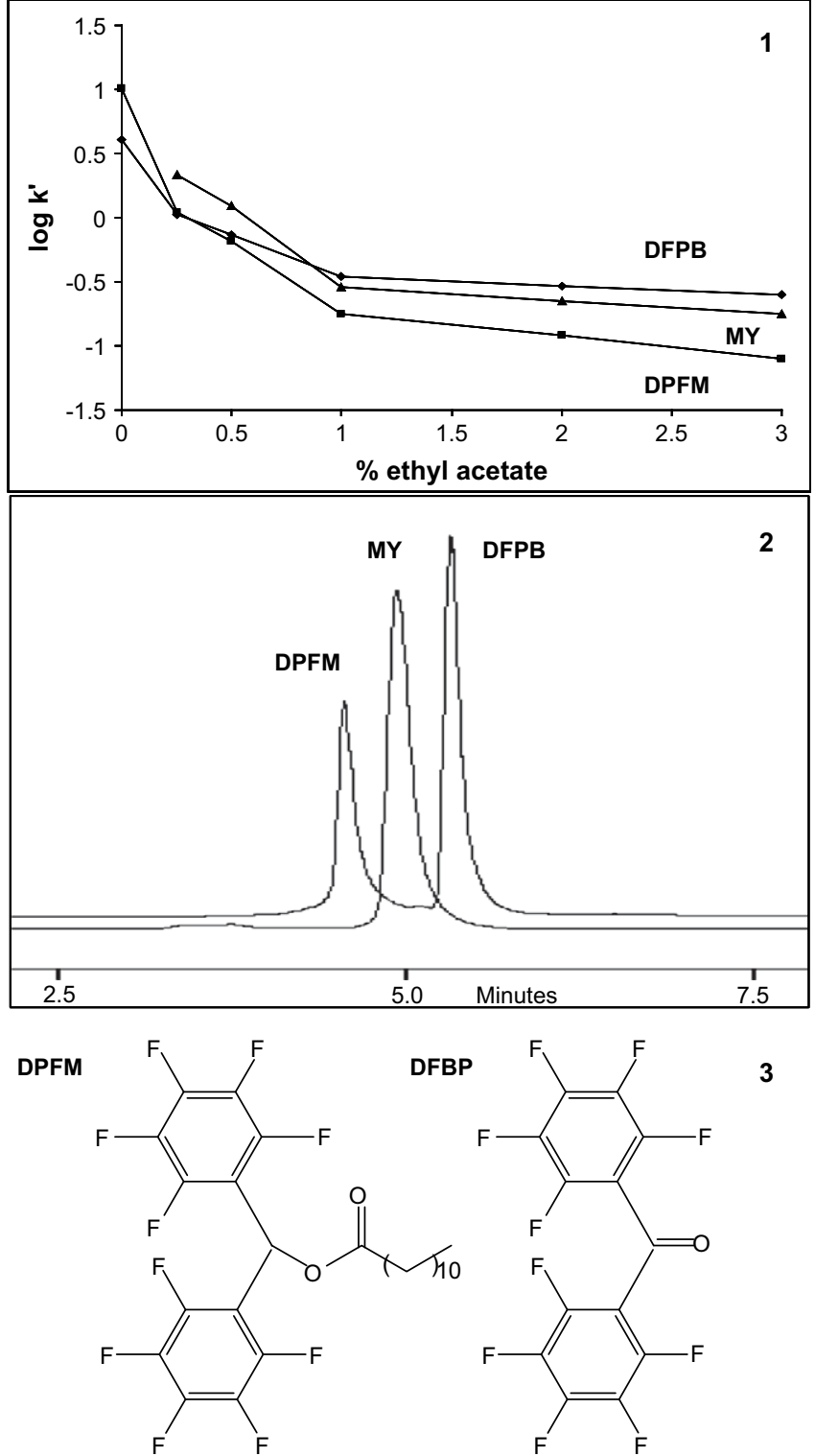

Figure 3. Optimisation of conditions for normal phase HPLC purification of multimethyl branched PFB esters, using chemical co-markers. (1) $\log k^{\prime}$ plot for decafluorobenzophenone (DFBP), mycocerosic acid PFB ester (MY) and dodecanoic acid bis-pentafuorophenyl-methyl ester (DPFM) as a function of ethyl acetate concentration (\%) in heptane. (2) The corresponding separation in 98:2 heptane:ethyl acetate, $1 \mathrm{ml} \mathrm{min}^{-1}$. Column, Genesis silica $4 \mu \mathrm{m}$ particle size, $250 \mathrm{~mm}$ by $4.6 \mathrm{~mm}$ at $30^{\circ} \mathrm{C}$. (3) Structures of the co-markers DPFM and DFBP.

\section{Table 2}

Retention factors of the decafluorobenzhydrol esters, mycocerosic acid PFB esters and decafluorobenzophenone.

\begin{tabular}{ll}
\hline Compound & $k^{\prime}$ \\
\hline Hexanoic acid bis-pentafluorophenyl-methyl ester & 0.26 \\
Octanoic acid bis-pentafluorophenyl-methyl ester & 0.18 \\
Dodecanoic acid bis-pentafluorophenyl-methyl ester (DPFM) & 0.12 \\
Hexadecanoic acid bis-pentafluorophenyl-methyl ester & 0.07 \\
Octadecanoic acid bis-pentafluorophenyl-methyl ester & 0.04 \\
Mycocerosic acid PFB ester (MY) & 0.22 \\
Decafluorobenzophenone (DFBP) & 0.29 \\
\hline
\end{tabular}

Chromatographic conditions: a Gilson 305 HPLC pump coupled to an Applied Biosystems 759A UV detector (263 nm) was used, with a Genesis silica $4 \mu \mathrm{m}$ column, $250 \mathrm{~mm}$ by $4.6 \mathrm{~mm}$ i.d., developed with an isocratic solvent system of $98: 2$ heptane:ethyl acetate $\left(1 \mathrm{ml} \mathrm{min}^{-1}\right)$ at $30^{\circ} \mathrm{C}$. 
shown in Table 1 . The resulting fractions were evaporated to dryness under $\mathrm{N}_{2}$ and analysed by TLC (Merck 1.05554 .001 silica gel $60 \mathrm{~F}_{254}$ aluminium-backed plates) developed with petroleum ether 60-80 ${ }^{\circ} \mathrm{C}$ : ethyl acetate, 9:1. The mycocerosic acid PFB esters were eluted in fractions 2 and $3\left(R_{f}=\sim 0.7\right)$ (Figure 2$)$.

\subsection{HPLC purification of mycocerosate PFB esters}

Fractions 2 and 3 from the preliminary normal phase cartridge separation were analysed by normal phase HPLC. The system used was a Gilson 305 HPLC pump with an Applied Biosystems 759A UV detector $(263 \mathrm{~nm})$. The column was a Jones Chromatography (Hengoed, Cardiff, UK) Genesis silica $4 \mu \mathrm{m}$ particle size, $250 \mathrm{~mm}$ by $4.6 \mathrm{~mm}$ i.d. The isocratic solvent system was $98: 2$ heptane:ethyl acetate $\left(1 \mathrm{ml} \mathrm{min}^{-1}\right)$ and the column was maintained at $30^{\circ} \mathrm{C}$. This system allowed the clear separation of multimethyl-branched fatty acid PFB esters (retention factor $k^{\prime}=0.24$ ) from other PFB fatty acid esters (retention factors $k^{\prime}=0.64-0.88$ ). A standard sample of mycocerosate PFB ester had a retention factor $k^{\prime}$ of 0.22 in this system (see Figure 3 and Table 2).

Two co-markers were developed to facilitate collection of the correct fraction eluting from the column. To allow detection at a similar UV wavelength, a range of compounds, with pentafluorophenyl chromophores and suitable polarities, were investigated. It was found that decafluorobenzophenone (DFBP) (Figure 3) (Fluorochem, Glossop, Derbyshire, UK) (retention factor $k^{\prime}=0.29$ ) eluted just after the multimethyl-branched fatty acid PFB esters (retention factor $k^{\prime}=0.22$ ). To obtain a co-marker which eluted just before the mycocerosate peaks, a range of long-chain $\left(C_{6}, C_{8}, C_{12}\right.$, $C_{16}$ and $C_{18}$ ) esters of decafluorobenzhydrol were prepared by reaction with hexanoyl, octanoyl, dodecanoyl, hexadecanoyl and octadecanoyl chlorides, as follows. Decafluorobenzhydrol $(50 \mathrm{mg}$, $1.4 \times 10^{-4} \mathrm{~mol}$ ) was placed in an $8.5 \mathrm{ml}$ PTFE capped tube and dissolved in anhydrous dichloromethane $(2 \mathrm{ml})$. The appropriate acid chloride $\left(1.4 \times 10^{-4} \mathrm{~mol}\right)$ was added along with 4-dimethylaminopyridine $\left(17 \mathrm{mg}, 1.4 \times 10^{-4} \mathrm{~mol}\right)$. The solution was shaken thoroughly and left to stand overnight at room temperature. The solution was washed with $10 \%$ aqueous $\mathrm{HCl}(2 \times 1 \mathrm{ml})$, followed by distilled water $(2 \times 1 \mathrm{ml})$, and dichloromethane evaporated under $\mathrm{N}_{2}$. The products were purified by preparative TLC in petrol $40^{\circ}-60^{\circ} \mathrm{C}$ : ethyl acetate, 9:1, $R_{f}=\sim 0.8$. The ${ }^{1} \mathrm{H}$ NMR $(200 \mathrm{~Hz}$, $\mathrm{CDCl}_{3}$ ) spectrum of dodecanoic acid bis-pentafluorophenyl-methyl ester showed $\delta$ : $0.8\left(\mathrm{t}, 3 \mathrm{H}, \mathrm{CH}_{3}\right), 1.2\left(\mathrm{~m}, 16 \mathrm{H}, 8 \times \mathrm{CH}_{2}\right), 1.6(\mathrm{~m}, 2 \mathrm{H}$,

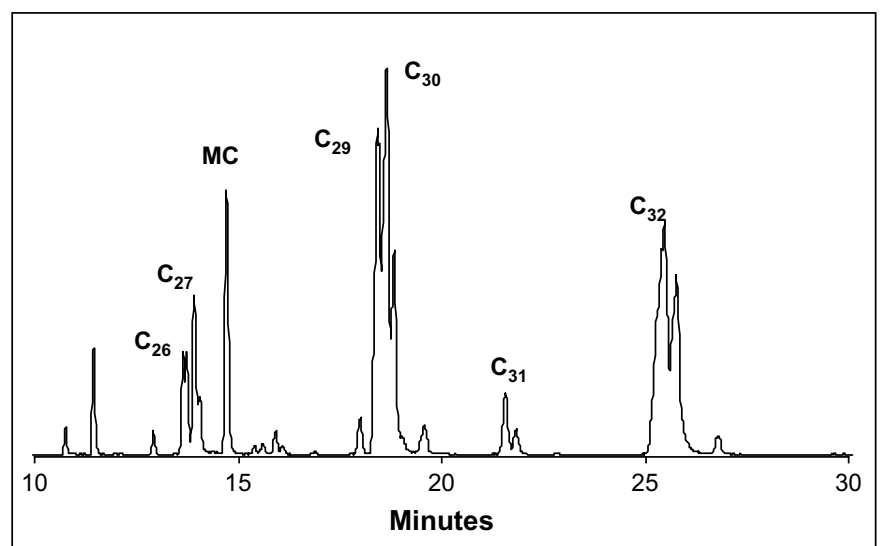

Figure 4. The total ion count (TIC) of PFB esters of the multimethyl-branched acids of M. tuberculosis. The TIC ( $m / z$ 350-550) was achieved using a Varian 1200L Quad MS (CI methane), with a Zebron ZB-5 ( $5 \%$ phenyl, $95 \%$ dimethylpolysiloxane) $30 \mathrm{~m}$ by $0.25 \mathrm{~mm}$ by $0.25 \mu \mathrm{m}$ capillary column and He as the carrier gas. The reactant gas was methane set at 3.6 Torr. The separation was achieved using a temperature program of $200-300{ }^{\circ} \mathrm{C}$ at a rate of $20^{\circ} \mathrm{C} \mathrm{min}^{-1}$, holding for $40 \mathrm{~min}$. The mycolipenate peak (MC) is identified ( $\left.\mathrm{m} / \mathrm{z} 407\right)$.
$\left.\mathrm{COCH}_{2} \mathrm{CH}_{2}\right), 2.4\left(\mathrm{t}, 2 \mathrm{H}, \mathrm{COCH}_{2}\right), 7.2(\mathrm{~s}, 1 \mathrm{H}, \mathrm{CH})$; the spectra of the other esters were essentially the same, with varying intensity for the long-chain signals.

Normal phase HPLC of the potential co-markers (Table 2) indicated that dodecanoic acid bis-pentafluorophenyl-methyl ester (DPFM) (Figure 3) was suitable as a co-marker (retention factor $k^{\prime}=0.12$ ), eluting prior to the mycocerosic acid PFB esters. Optimum concentrations of the markers were chosen as the minimum amount that could be clearly seen at the maximum sensitivity of the UV detector. For the co-marker DPFM, this was determined to be $0.01 \mathrm{M}$ in heptane; for co-marker DFPB this was determined to be $0.005 \mathrm{M}$ in heptane. The solutions were mixed in a $1: 1$ ratio and $2.5 \mu \mathrm{l}$ was added to each injection sample.

\subsection{Extraction and purification of natural biomarkers}

The non-hydroxylated fatty acid fractions, extracted from bone samples, were converted to PFB esters as detailed above. The crude esters were further fractionated using a normal phase Alltech 209250 cartridge, IST Vacmaster vacuum tank and elution system (Table 1), as outlined above. Fractions 2 and 3 from these separations were combined, evaporated to dryness, dissolved in HPLC grade heptane $(20 \mu \mathrm{l})$ and $2.5 \mu \mathrm{l}$ of the co-marker solution added, corresponding to
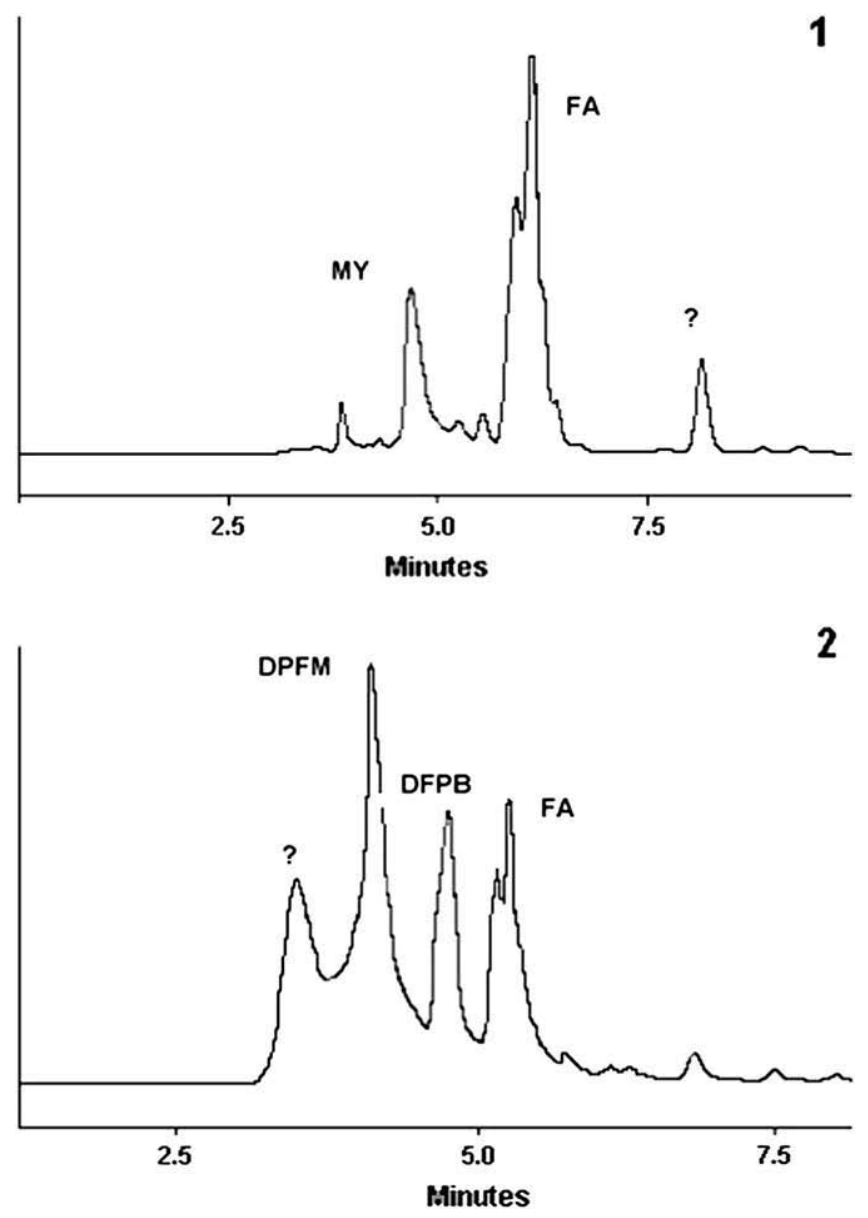

Figure 5. The HPLC separation of multimethyl-branched PFB esters (MY) from non-multi-methyl branched PFB esters (FA) in a M. tuberculosis cell extract (1) and archaeological bone Coimbra sample 8 (2), containing the two co-markers dodecanoic acid bis-pentafluorophenyl-methyl ester (DPFM) and decafluorobenzophenone (DFPB). Column, Genesis silica $4 \mu \mathrm{m}$ particle size, $250 \mathrm{~mm}$ by $4.6 \mathrm{~mm}$ at $30^{\circ} \mathrm{C}$. Eluent, $98: 2$ heptane:ethyl acetate $\left(1 \mathrm{ml} \mathrm{min}^{-1}\right), 263 \mathrm{~nm}$. FA refers to probable PFB esters of non-hydroxylated fatty acids from endogenous bone lipids and M. tuberculosis. 
a concentration of $1.25 \times 10^{-8} \mathrm{~mol}$ dodecanoic acid bis-pentafluorophenyl-methyl ester and $6.25 \times 10^{-10} \mathrm{~mol}$ decafluorophenylbenzophenone. The solution was evaporated to dryness under $\mathrm{N}_{2}$. HPLC grade heptane $(10 \mu \mathrm{l})$ was added to each sample and the sample was injected into the HPLC system. As above, the column was a Genesis silica $4 \mu \mathrm{m}$ particle size, $250 \mathrm{~mm}$ by $4.6 \mathrm{~mm}$ i.d. and the isocratic solvent system was $98: 2$ heptane:ethyl acetate $\left(1 \mathrm{ml} \mathrm{min}^{-1}\right)$, with detection at $263 \mathrm{~nm}$. Collection of the mycocerosate PFB fraction began when the peak of the co-marker DPFM appeared and continued until the appearance of the co-marker DFBP; the collected fraction was evaporated to dryness under $\mathrm{N}_{2}$. Between sample injections, the syringe was washed 40 times with HPLC grade heptane and the Rheodyne injection valve was washed 10 times in both the load and inject position. Blanks (heptane) were injected between each sample to ensure there was no cross-contamination.

\subsection{NI-CI GC-MS conditions for analysis of PFB esters}

SIR NI-CI GC-MS analyses of the purified PFB fractions were carried out at the Universities of Greenwich and Salford. In the initial study (Greenwich), a $30 \mathrm{~m}$ by $0.25 \mathrm{~mm}$ i.d. by $0.25 \mu \mathrm{m}$ film (Scientific Glass Engineering, Milton Keynes, UK) BPX-5 (5\% phenyl polysilphenyl-siloxane) capillary column (He carrier gas, column head pressure $10 \mathrm{psi}$; CI ammonia) was used in a VG 305 MS, using a $15{ }^{\circ} \mathrm{C} / \mathrm{min}$ temperature gradient from 175 to $300^{\circ} \mathrm{C}$. The dried samples were dissolved in $20 \mu \mathrm{l}$ octane, and $1 \mu \mathrm{l}$ introduced through an autoinjector in splitless injection mode. Octane blanks were injected between samples.

In the quantitative study (Salford), a Varian 1200L Quad MS (CI methane, 3.6 Torr) was fitted with a Phenomenex (Macclesfield, Cheshire, UK) Zebron ZB-5 (5\% phenyl, 95\% dimethylpolysiloxane) $30 \mathrm{~m}$ by $0.25 \mathrm{~mm}$ i.d. by $0.25 \mu \mathrm{m}$ film capillary column, using a head pressure of 8 psi and a gradient from 200 to $300^{\circ} \mathrm{C}$ at $20^{\circ} \mathrm{C} / \mathrm{min}$ and holding at this temperature for $40 \mathrm{~min}$. The ion source temperature was $260^{\circ} \mathrm{C}$, the injector $250^{\circ} \mathrm{C}$ and the transfer line $300^{\circ} \mathrm{C}$. The dried samples were dissolved in $20 \mu \mathrm{l}$ octane, and $1 \mu \mathrm{l}$ injected, using direct splitless injection. Octane blanks were analysed between samples, with a temperature range from 200 to $350{ }^{\circ} \mathrm{C}$ at $20^{\circ} \mathrm{C} \mathrm{min}^{-1}$, over $27.5 \mathrm{~min}$. Data were collected, using Varian MS Workstation software, version 6.2.

At Greenwich, it was possible to monitor a wide range of ions, but the data system did not allow the collection of quantitative data; the ions studied were $m / z 395$ ( $C_{26}$ mycocerosic acid), 409 $\left(C_{27}\right), 437\left(C_{29}\right), 451\left(C_{30}\right), 479\left(C_{32}\right), 493\left(C_{33}\right)$ and $507\left(C_{34}\right)$. Additionally, most extracts were monitored for $\mathrm{m} / \mathrm{z} 407$, corresponding to $\mathrm{C}_{27}$ mycolipenate (Figure 1). In the light of the
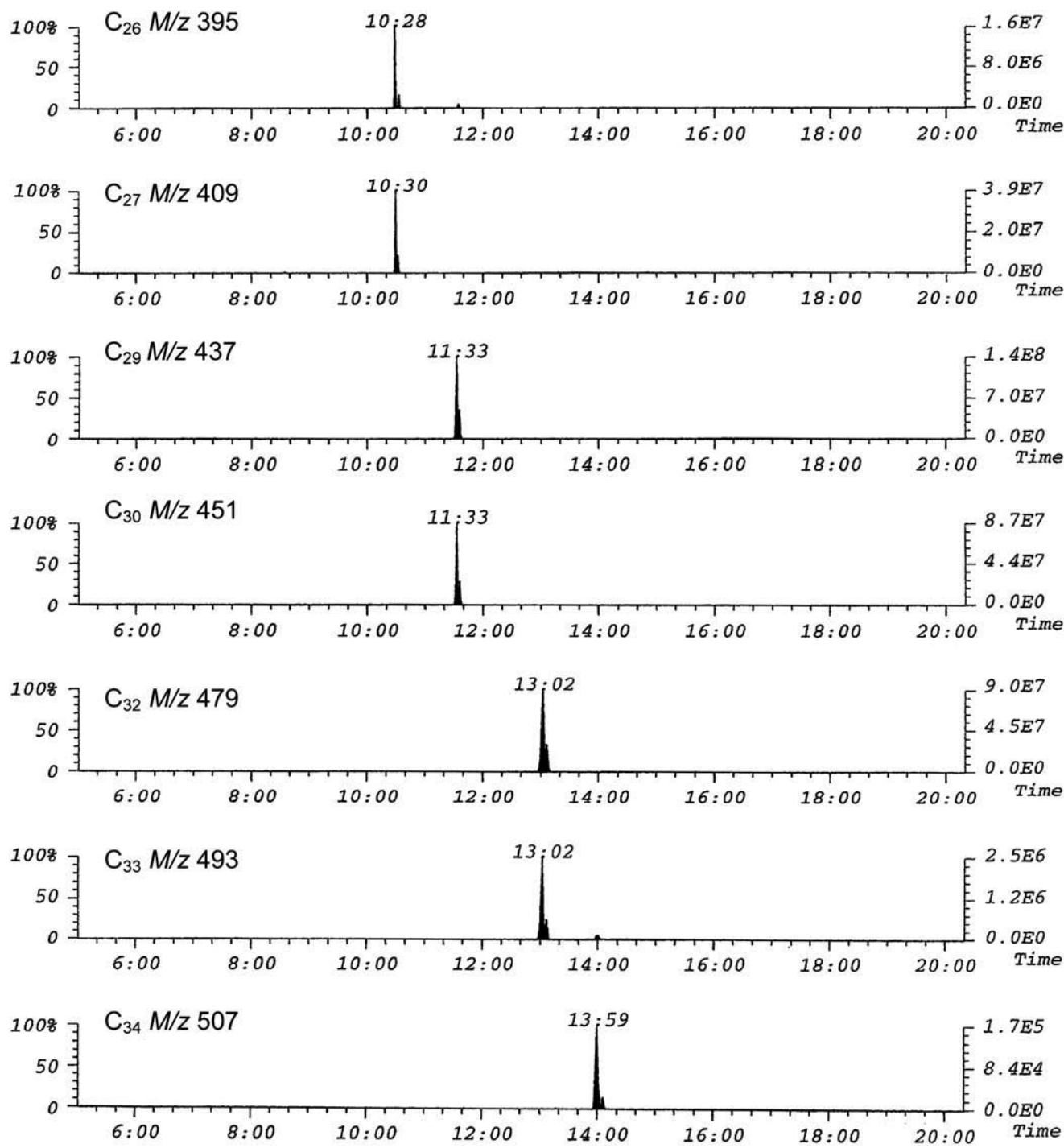

Figure 6. SIM chromatogram of purified mycocerosic acid PFB esters from M. tuberculosis PN, using a BPX-5 column in Greenwich. 
Greenwich results, it was decided to concentrate, at Salford, on obtaining quantitative data for the main characteristic $\mathrm{m} / \mathrm{z} 437$ $\left(C_{29}\right), 451\left(C_{30}\right)$ and $479\left(C_{32}\right)$ mycocerosate ions, measuring peak areas. $A C_{31}$ standard, hentriacontanoic acid PFB ester, $m / z$ 465, was used for relative retention and calibration studies at Salford.

\section{Results and discussion}

\subsection{Extraction and purification of long-chain compounds}

The PDIM waxes are extremely resistant to hydrolysis in aqueous media. ${ }^{45}$ To obtain efficient release of the mycocerosic acids and phthiocerol components of PDIMs, the current low water alkaline hydrolysis procedure was developed. ${ }^{37,38}$ The suitability of this protocol was demonstrated by the efficient release of longchain compounds from the standard mycobacteria. The waterlimited conditions of the alkaline hydrolysis stage were also designed to promote racemization of the chiral centre at carbon-2 of the mycocerosates to produce diagnostic diastereoisomers due to the presence of an additional chiral methyl branch at carbon- 4 . As shown later, these diastereoisomers can be distinguished on gas chromatography of their PFB esters, visible as a second smaller peak immediately following the major peak. In contrast, mycolipenic acid derivatives produce a single peak as there is no chiral centre at carbon-2 (Figure 4).

The released acidic components of hydrolysates were converted to PFB esters by an efficient phase-transfer catalysis procedure. ${ }^{44}$ Long-chain components were separated on silica gel cartridges to produce fractions enriched in multimethyl-branched PFB esters, PFB esters of mycolates and underivatised phthiocerols, as shown in Figure 2 for standard extracts of M. tuberculosis. Fractions 2 and 3, contained the multimethyl-branched PFB esters (Figure 2), but they were accompanied by the usual $C_{12}-C_{18}$ fatty acids, found in cellular plasma membrane lipids. To ensure effective GC-MS analyses, these fractions were further purified by normal phase HPLC.

The HPLC profile for the combined fractions 2 and 3 from standard $M$. tuberculosis is shown in Figure 5. As shown by comparison with standard PFB mycocerosates, the multimethyl-

Table 3

Correlation of mycocerosic acid detection with the burial record and state of bone preservation.

\begin{tabular}{|c|c|c|c|c|c|}
\hline Lab. No. & Coimbra No. & State* & Cause of death & Mycocerosic acids & Burial correlation \\
\hline$\overline{1}$ & 6 & $G$ & Enteric TB & + & 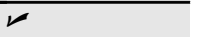 \\
\hline 2 & 88 & $\mathrm{P}$ & Pulmonary gangrene & + & \\
\hline 3 & 229 & M & Pulmonary TB & + & $\nu$ \\
\hline 4 & 355 & $\mathrm{P}$ & Pulmonary TB & + & レ \\
\hline 5 & 289 & G & Pulmonary TB & + & $\boldsymbol{}$ \\
\hline 6 & 59 & $\mathrm{P}$ & Meningitis & + & \\
\hline 7 & 94 & $\mathrm{P}$ & Chronic bronchitis & - & $\boldsymbol{}$ \\
\hline 8 & 239 & M & Pulmonary TB & + & $\boldsymbol{V}$ \\
\hline 9 & 210 & G & Typhoid fever/heart failure & + & \\
\hline 10 & 252 & G & Pulmonary TB & + & レ \\
\hline 11 & 338 & M & Pulmonary TB & + & $\nu$ \\
\hline 12 & 36 & G & Pulmonary TB & + & レ \\
\hline 13 & 403 & G & Pulmonary TB & + & $\boldsymbol{}$ \\
\hline 14 & 286 & M & Peritoneal/pleural TB with hepatitis & + & $\boldsymbol{V}$ \\
\hline 15 & 416 & $\mathrm{P}$ & Pulmonary TB & + & レ \\
\hline 16 & 114 & G & Spine column fracture & + & \\
\hline 17 & 178 & $\mathrm{P}$ & Tumour on mediastinum & + & \\
\hline 18 & 226 & G & Bilateral pulmonary TB & + & レ \\
\hline 19 & 104 & $\mathrm{P}$ & Bilateral bronchopneumonia & + & 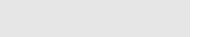 \\
\hline 20 & 412 & G & Meningitis TB & + & $\boldsymbol{V}$ \\
\hline 21 & 47 & $\mathrm{P}$ & Pulmonary TB & + & $\boldsymbol{V}$ \\
\hline 22 & 401 & M & Pulmonary TB & + & $\boldsymbol{V}$ \\
\hline 23 & 432 & $\mathrm{P}$ & Pulmonary TB & + & レ \\
\hline 24 & 349 & G & Devastating haemoptysis & + & \\
\hline 25 & 473 & $\mathrm{P}$ & Pulmonary TB & + & $\nu$ \\
\hline 26 & 123 & $\mathrm{P}$ & Cardiac arrhythmia & + & \\
\hline 27 & 120 & G & Aorta aneurysm & + & \\
\hline 28 & 105 & M & Pulmonary TB & + & 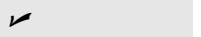 \\
\hline 29 & 70 & G & Pneumonic & + & \\
\hline 30 & 16 & M & Enteritis/meningitis & + & \\
\hline 31 & 181 & $\mathrm{P}$ & Pulmonary TB & + & 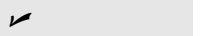 \\
\hline 32 & 196 & $\mathrm{P}$ & Pulmonary TB & - & \\
\hline 33 & 171 & G & Pulmonary TB & + & 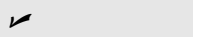 \\
\hline 34 & 72 & M & Cardiac arrhythmia/progressive paralysis & - & 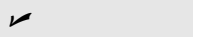 \\
\hline 35 & 80 & $\mathrm{P}$ & Pulmonary TB & + & 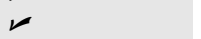 \\
\hline 36 & 110 & M & Pneumonia & - & $\nu$ \\
\hline 37 & 116 & G & Heart failure & - & 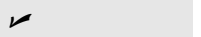 \\
\hline 38 & 306 & G & Pulmonary TB & + & $\nu$ \\
\hline 39 & 113 & $\mathrm{P}$ & Epilepsy & - & 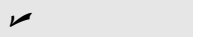 \\
\hline 40 & 246 & G & Pulmonary TB & - & \\
\hline 41 & 85 & G & Myocarditis/meningeal haemorrhage & - & $\swarrow$ \\
\hline 42 & 35 & M & Chronic endocarditis & - & 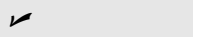 \\
\hline 43 & 56 & M & Heart lesion & - & 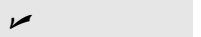 \\
\hline 44 & 62 & M & Brain haemorrhage & - & 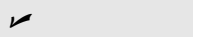 \\
\hline 45 & 17 & $\mathrm{P}$ & Brain haemorrhage & - & $\swarrow$ \\
\hline 46 & 98 & M & Heart failure/myocarditis/asphyxia & - & 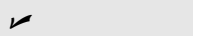 \\
\hline 47 & 108 & $\mathrm{P}$ & General paralysis & - & $\nu$ \\
\hline 48 & 68 & G & Alcoholism and sudden death & - & $\swarrow$ \\
\hline 49 & 24 & M & Dorsal "astomo" & - & 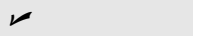 \\
\hline
\end{tabular}

* State of preservation of the bone, as judged by weight and friability alone. ( $G=$ good, $M=$ moderate, $P=$ poor). 
branched components could be clearly separated from the other smaller PFB esters. Any PFB mycocerosate esters present in an archaeological sample would be below the UV detection limit, so suitable co-markers, DPFM and DFBP, were developed (Figure 5), eluting immediately before and after the mycocerosates. This allowed successful collection and purification of the mycocerosate fractions from archaeological material.

The co-markers were chosen to have essentially the same UV chromophore as the PFB esters. Conveniently, decafluorobenzophenone (DFBP) (Figure 3) was found to elute just after the PFB fraction containing the PFB mycocerosates. To obtain a suitable marker, eluting before the PFB mycocerosates, a range of long-chain esters of decafluorobenzhydrol were prepared (Table 2); it was found that dodecanoic acid bis-pentafluorophenyl-methyl (DPFM) ester eluted just before the PFB fraction containing the PFB mycocerosates (Figure 5). Standard solutions were prepared for addition to the archaeological samples.

\subsection{Diagnostic ion selection}

Using the mycocerosic acid fraction from the standard M. tuberculosis, M. marinum, $M$. bovis and $M$. kansasii cells (data not shown), which correlated with published data, ${ }^{38}$ ions at $\mathrm{m} / \mathrm{z} 395$ ( $C_{26}$ mycocerosic acid $), 409\left(C_{27}\right), 437\left(C_{29}\right), 451\left(C_{30}\right), 479\left(C_{32}\right)$, $493\left(C_{33}\right)$ and $507\left(C_{34}\right)$ were scrutinised in the initial study of the archaeological samples at Greenwich. Additionally, in the majority of the analyses the $C_{27}$ mycolipenate ion at $m / z 407$ was monitored. No definitive ion signals were observed for the dimethyl-branched $C_{26}$, pentamethyl-branched $C_{33}$ and tetramethyl-branched $C_{34}$ mycocerosates and these acids were excluded from this study. The $\mathrm{C}_{27}$ mycocerosate ion $(\mathrm{m} / \mathrm{z} 409)$ has value as a marker for M. marinum and $M$. bovis, being prevalent in both species ${ }^{31,38,40}$; M. kansasii did not appear to be a contaminant of the site, as the profiles had major amounts of the $C_{32}$ mycocerosate. The most intense ions present in mycocerosic acid fraction from the standard M. tuberculosis PN cells (Figure 6) were $m / z 437\left(C_{29}\right), m / z 451\left(C_{30}\right)$ and $m / z 479\left(C_{32}\right)$, in agreement with previous studies $31,36,38,40$; these ions were used for quantitative screening at Salford.

\subsection{The sample set}

The chosen individuals had been clinically examined between 1837 and 1936. Current TB diagnosis uses abnormal chest radiograph findings consistent with TB, fever, weight loss, a history of TB, a positive result on tuberculin skin test and haemoptysis. The initial indications are supported by laboratory confirmation, but even with all these modern tools, a diagnosis of TB is sometimes missed. ${ }^{46}$ The sample set did not include individuals less than 15 years old at death, since diagnosis without laboratory support is much more problematic in children. ${ }^{47}$ In modern cases, primary disease and its complications are more common in children than in adults, leading to differences in both clinical and radiographic manifestations ${ }^{48}$; the sample set, therefore, was restricted to adults. The sample set was designed to include $50 \%$ of individuals recorded to have died from tuberculosis (Table 3 ).

\subsection{Initial study (Greenwich)}

Summaries of the results obtained at the two centres are shown in Tables 3 and 4 . In the initial analyses, carried out at Greenwich, it was possible to monitor seven negative ions $(\mathrm{m} / \mathrm{z} 395,409,437,451$, $479,493,507$ ), corresponding to $C_{26}, C_{27}, C_{29}, C_{30}, C_{32}, C_{33}$ and $C_{34}$ mycocerosate carboxylates, as well as $m / z 407$, corresponding to the $\mathrm{C}_{27}$ mycolipenate (Table 4 ). A typical profile for a strongly positive bone sample (C8), determined in Greenwich, is shown in Figure 7.
As expected, $C_{29}, C_{30}$ and $C_{32}$ mycocerosates were present, but there was also a comparable $C_{27}$ mycocerosate. No evidence was seen for $C_{26}, C_{33}$ or $C_{34}$ mycocerosates in $C 8$ or in any of the other bone extracts studied. The peak at 9:38 for $m / z 395$ (Figure 7) is not $C_{26}$ mycocerosate; it is not a double peak and its retention time does not coincide with that (10:32) of $C_{27}$ mycocerosate, as shown in the profile (Figure 6) for the standard mycocerosates from $M$. tuberculosis. The profile for $\mathrm{C} 8$, did, however, show the presence of a signal attributable to $\mathrm{C}_{27}$ mycolipenate and several other extracts were positive. The presence or absence of mycolipenates in the Coimbra bone extracts is summarized in Table 4 . The low intensity of the $\mathrm{m} / \mathrm{z}$ 407 signal, in a minority of samples (Table 4), indicated that the mycolipenate ion is a less effective biomarker for tuberculosis.

\subsection{Quantitative study (Salford)}

Using standard M. tuberculosis PN cells and hentriacontanoic acid $\left(C_{31}, m / z 465\right)$ as an internal marker, the relative retention of the $C_{29}, C_{30}$ and $C_{32}$ ions on the Zebron ZB-5 column was $0.46,0.47$ and 0.63 , respectively. To ascertain system performance, a six point calibration of hentriacontanoic acid, $18-3500 \mathrm{nM} \mathrm{l}^{-1}$ was undertaken. The linearity of the system was good, with a regression coefficient of 0.9995. The detection limit was calculated as 1.34 femtomoles, defined as twice the average peak to peak

\section{Table 4}

Distribution of mycocerosates and mycolipenates in Coimbra bone extracts and standard material. Semi-quantitative data were obtained in Greenwich (G) and quantitative ratios of $C_{29}, C_{30}$ and $C_{32}$ mycocerosate ions were recorded in Salford (S).

\begin{tabular}{|c|c|c|c|c|c|c|c|c|}
\hline Sample & $\mathrm{C}_{27}$ & $\mathrm{C}_{27}$ & $\mathrm{C}_{29}$ & $\mathrm{C}_{29}$ & $C_{30}$ & $\mathrm{C}_{30}$ & $\mathrm{C}_{32}$ & $\mathrm{C}_{32}$ \\
\hline$\overline{m / z}$ & 407 & 409 & 437 & 437 & 451 & 451 & 479 & 479 \\
\hline Laboratory & G & G & G & $\mathrm{S}$ & G & S & G & $\mathrm{S}$ \\
\hline M. marinum & & & & 0.71 & & 0.28 & & 0.01 \\
\hline M. kansasii & & & & 0.16 & & 0.80 & & 0.04 \\
\hline M. bovis & & & & 0.77 & & 0.13 & & 0.10 \\
\hline M. tuberculosis & & & & 0.34 & & 0.25 & & 0.41 \\
\hline 1 & + & & +++ & 0.27 & + & 0.13 & +++ & 0.60 \\
\hline 2 & & & +++ & 0.25 & ++ & 0.26 & +++ & 0.49 \\
\hline 3 & & & +++ & 0.29 & ++ & 0.18 & +++ & 0.53 \\
\hline 4 & + & & +++ & 0.25 & ++ & 0.22 & +++ & 0.52 \\
\hline 5 & ND & & +++ & 0.16 & ++ & 0.13 & +++ & 0.71 \\
\hline 6 & & +++ & +++ & 0.12 & ++ & 0.16 & +++ & 0.72 \\
\hline 8 & + & ++ & +++ & 0.21 & ++ & 0.19 & +++ & 0.60 \\
\hline 9 & + & +++ & +++ & 0.15 & ++ & 0.17 & +++ & 0.68 \\
\hline 10 & + & ++ & +++ & 0.13 & ++ & 0.14 & +++ & 0.73 \\
\hline 11 & + & & +++ & 0.12 & ++ & 0.17 & +++ & 0.71 \\
\hline 12 & & & +++ & 0.27 & & 0.18 & +++ & 0.55 \\
\hline 13 & + & & +++ & 0.32 & ++ & 0.19 & +++ & 0.49 \\
\hline 14 & & & +++ & 0.14 & ++ & 0.13 & +++ & 0.73 \\
\hline 15 & & & +++ & 0.25 & & 0.12 & +++ & 0.63 \\
\hline 16 & & & +++ & 0.42 & & 0.20 & +++ & 0.38 \\
\hline 17 & & & +++ & 0.21 & +++ & 0.17 & ++ & 0.62 \\
\hline 18 & & & +++ & 0.22 & +++ & 0.15 & +++ & 0.63 \\
\hline 19 & + & & +++ & 0.17 & ++ & 0.12 & +++ & 0.71 \\
\hline 20 & & & +++ & 0.24 & +++ & 0.13 & +++ & 0.63 \\
\hline 21 & & & +++ & 0.26 & ++ & 0.18 & +++ & 0.56 \\
\hline 22 & & & +++ & 0.18 & +++ & 0.36 & +++ & 0.46 \\
\hline 23 & & & +++ & 0.33 & +++ & 0.14 & +++ & 0.53 \\
\hline 24 & & & +++ & 0.35 & & 0.19 & +++ & 0.46 \\
\hline 25 & & & +++ & 0.23 & ++ & 0.11 & +++ & 0.66 \\
\hline 26 & & & +++ & 0.63 & ++ & 0.10 & +++ & 0.27 \\
\hline 27 & & & & 0.37 & & 0.11 & & 0.52 \\
\hline 28 & & ++ & +++ & 0.40 & ++ & 0.28 & +++ & 0.32 \\
\hline 29 & + & & +++ & 0.43 & ++ & 0.13 & +++ & 0.44 \\
\hline 30 & & & +++ & 0.44 & ++ & 0.18 & +++ & 0.38 \\
\hline 31 & & & +++ & 0.43 & ++ & 0.11 & +++ & 0.46 \\
\hline 33 & & & & 0.58 & & 0.26 & & 0.16 \\
\hline 35 & & & +++ & 0.19 & ++ & 0.18 & +++ & 0.63 \\
\hline 38 & & & ++ & 0.07 & ++ & 0.04 & +++ & 0.89 \\
\hline
\end{tabular}



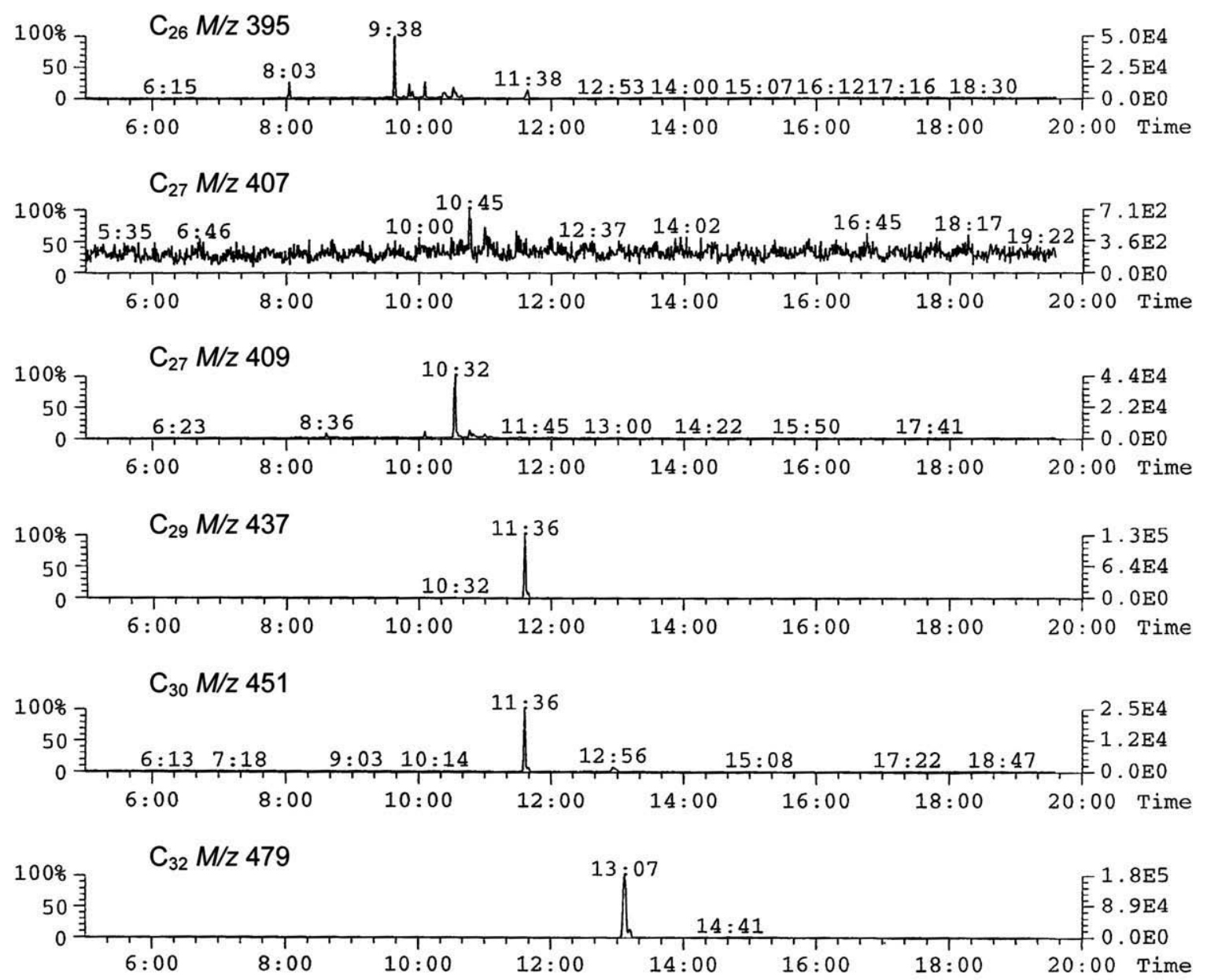

$\mathrm{C}_{33} M / z 493$

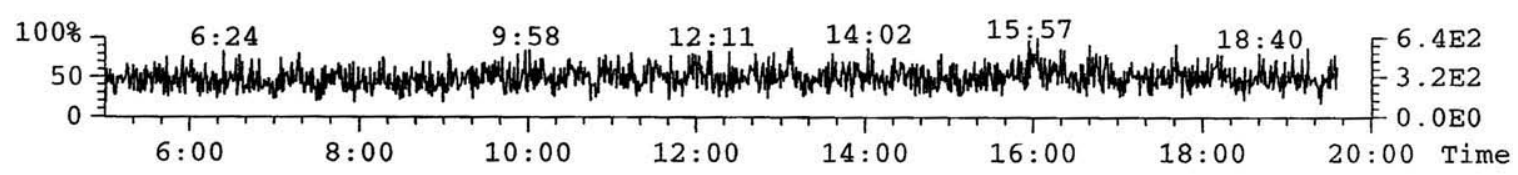

$\mathrm{C}_{34} M / z 507$

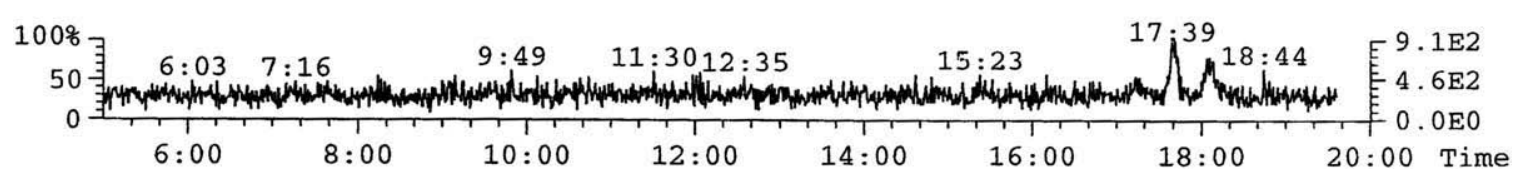

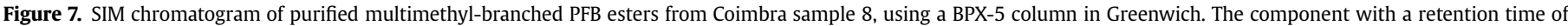
$10.45 \mathrm{~min}$, corresponds to $\mathrm{C}_{27}$ mycolipenate $(\mathrm{m} / \mathrm{z} 407)$.

baseline, for a $1 \mu \mathrm{L}$ injection. Due to the similarity of mycocerosate structure, a similar response was assumed for each component. A GC-MS total ion count (TIC) profile of the multimethyl-branched fraction purified from $M$. tuberculosis PN is shown in Figure 4. As well as the expected mycocerosates, a substantial amount of $C_{27}$ mycolipenate is present as a single peak.

At Salford, the analysis was limited to the trimethyl-branched $\mathrm{C}_{29}(\mathrm{~m} / \mathrm{z} 437)$ and tetramethyl-branched $\mathrm{C}_{30}(\mathrm{~m} / \mathrm{z} 451)$ and $\mathrm{C}_{32}(\mathrm{~m} / \mathrm{z}$ $479)$ mycocerosates in order to obtain good quantitative data. The $C_{32}$ mycocerosate (Table 4 ) is usually the major component in $M$. tuberculosis resulting in the ion $m / z 479$, as shown in previous studies, ${ }^{36-40}$ with the double peaks for $C_{29}(\mathrm{~m} / \mathrm{z} 437)$ and $C_{30}(\mathrm{~m} / \mathrm{z}$
451) also present (Table 4). Typical profiles for the same strong positive sample (C8), as recorded at Greenwich (Figure 7), and a weak positive (C26) are shown in Figure 8.

\subsection{Correlation of results}

The results summarized in Table 4 provide a good correlation between the two separate Greenwich and Salford analyses. However, the enhanced sensitivity of the more focused study, in Salford, was able to detect two additional positive extracts (Table 4, $\mathrm{C} 27,33)$. The data for the positive samples from the Coimbra extracts are correlated in Table 3 . It is notable that in the less quantitative 

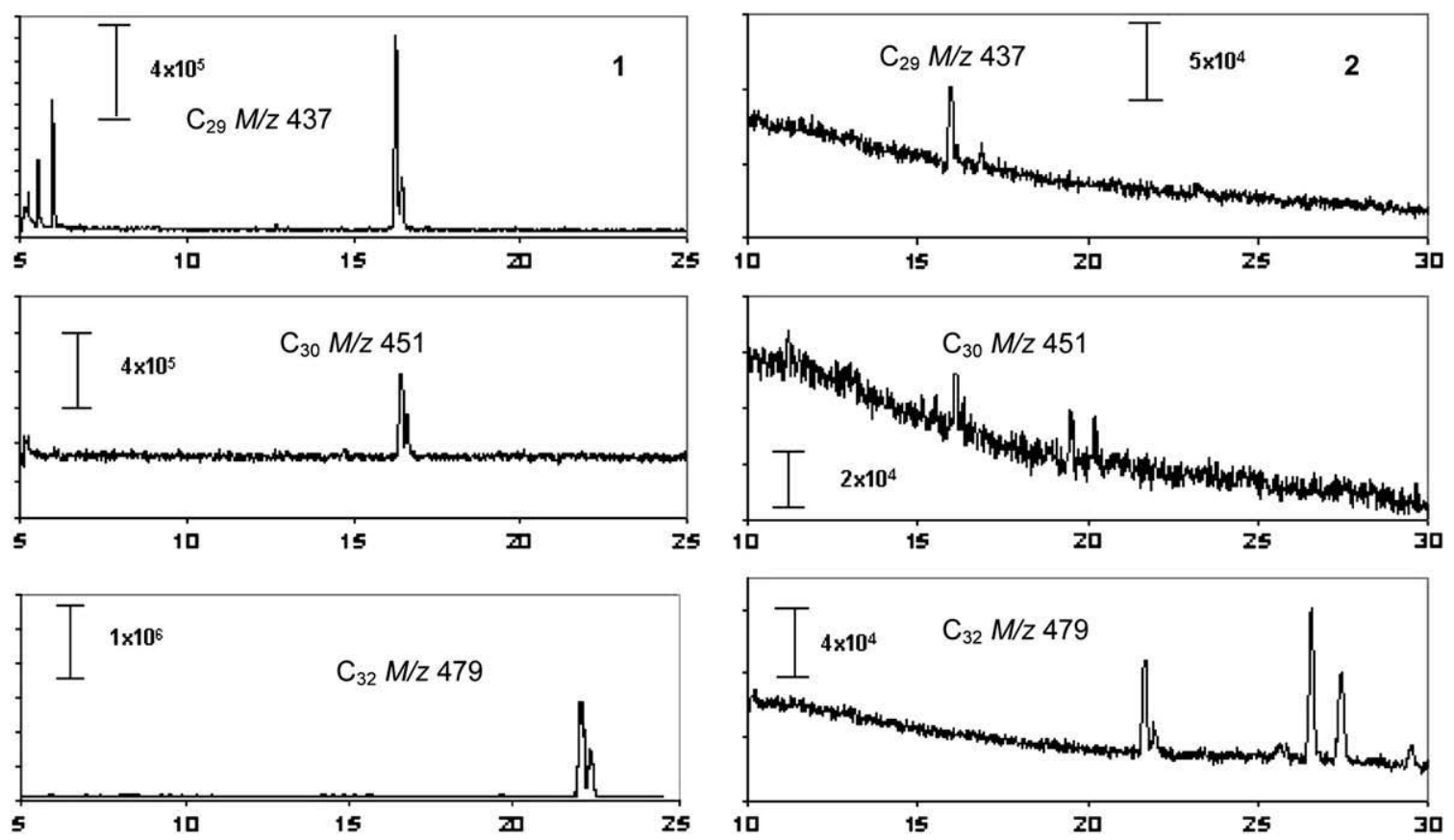

Figure 8. SIM chromatograms for Coimbra sample 8, a strong positive (1) and sample 26, a weak positive (2), using a Zebron ZB-5 column in Salford.

Greenwich study the signals for the $\mathrm{C}_{29}(\mathrm{~m} / \mathrm{z} 437)$ mycocerosate were apparently enhanced (Table 3). Of the 49 ribs analysed, 16 (33\%) were negative and others displayed various degrees of positivity. In most of the 33 positive cases (Table 3 ) the principle components were the $C_{29}$ and $C_{32}$ mycocerosates, at $m / z 437$ and 479 . This is in accord with the profiles of mycocerosates in M. tuberculosis. ${ }^{36-40}$ The $C_{32}$ mycocerosate was the major component in 28 (85\%) of the 33 positive samples and in 7 of these (Table $4 ; C 5,6,10,11,14,19,38$ ) it comprised more than $70 \%$ of the mycocerosates (Table 4 ). Of these 28 samples, 23 had $\mathrm{C}_{29}$ as the next most abundant mycocerosate (Table $4 ; C 1,2,3-5,8,12-15,17-21,23-25,27,29,31,35,38)$ and $C_{29}$ was the major mycocerosate in 5 (Table 4 ; C16, 26, 28, 30, 33) of the 33 positive samples. The $C_{30}$ mycocerosate was usually the minor component, except for 6 samples (Table 4; C2, 6, 9-11, 22) where it predominated over the $\mathrm{C}_{29}$ ester.

It is of interest to correlate the mycocerosic acid detection to the burial record (Table 3). Of the 33 mycocerosate positive samples, 22 of these correlated with a positive diagnosis for tuberculosis; only 2 skeletons diagnosed with pulmonary tuberculosis were negative for mycocerosates (Table 3; C32, 40). Eleven isolates (Table 3; C2, 6, $9,16,17,19,24,26,27,29,30$ ) were positive for mycocerosates without an indication of tuberculosis; this indicates that specific lipid biomarkers can detect tuberculosis before bone lesions, or other physical manifestations, appear.

\subsection{Preservation potential of the biomarker}

The diagnosis of tuberculosis in archaeological skeletal samples can be more difficult than for living patients, as there is no living patient to assess signs and symptoms and often no associated specific pathological change. Another problem, aside from site contamination, is the diagenetic (post-mortem modification by a variety of routes) alteration of the biomarker. Although more resistant than other types of biomolecule, ${ }^{49}$ lipids such as mycocerosic acids are potentially susceptible to diagenetic change. The main route of diagenesis for many lipids is hydrolysis of the ester bond followed by decarboxylation ${ }^{50}$; generally, long-chain fatty acids $\left(C_{20}-C_{34}\right)$ are more resistant than shorter chain analogues. ${ }^{51}$
Diagenetic change, resulting in mycocerosic acid decarboxylation would make the resulting alkane undetectable, as it could not be derivatised.

There is also a hierarchy for stability with unsaturated fatty acids being more reactive than branched fatty acids, which are more reactive than straight-chain fatty acids. ${ }^{52}$ It is unlikely, however, that diagenetic reactions would result in an enrichment with longer chain mycocerosic acids, since no simple relationship exists between the rate of diagenetic loss and chain length. ${ }^{53,54}$ High concentrations of $\mathrm{C}_{32}$ mycocerosate surviving in the bone are therefore strongly indicative of members of the $M$. tuberculosis complex, allowing no confusion with any other mycobacteria.

The form in which these lipids exist in the bone may have an effect on survival. Mycocerosic acids are diesterified to the phthiocerols, with the resultant phthiocerol dimycocerosate being over 100 carbons in size and highly resistant to hydrolysis. ${ }^{45}$ Additionally, mycocerosic acids are present as the lipid moiety in phenolic glycolipids (PGLs) found in M. bovis and unusual "Canetti" variants of $M$. tuberculosis. ${ }^{32,33,35}$ The hydrophilic sugar moieties of PGLs might be relatively more susceptible to diagenetic loss.

The detection of $\mathrm{C}_{27}$ mycolipenates in a significant number of samples (Table 4) is interesting. Mycolipenates occur as diacyl trehaloses $^{33}$ and these relatively polar glycolipids would be expected to degrade more rapidly. However, diacyl trehaloses are less regularly encountered than phthiocerol dimycocerosates, ${ }^{33}$ so it is unclear if the reduced detection (Table 4) is due to selective diagenesis, perhaps due to the presence of a double bond, or limited synthesis in the original infecting agent.

Preservation of fatty acids would be further enhanced from their inclusion into microbially inaccessible matrices. ${ }^{55}$ Fatty acids adsorb to the surface pores of natural geosorbents ${ }^{56}$ and are protected from degradation. ${ }^{55}$ Fatty acids not protected by mineral pores have an average turnover time of between 21 and 49 years. ${ }^{57}$ Bone contains such small pores ${ }^{54,58}$ and it is hypothesized that these afford protection for the mycobacterial lipids. Bones were graded as good, moderate and poor (Table 3), but the degree of bone degradation did not appear to have an effect on mycocerosate recovery. 


\section{Conclusions}

Mycocerosic acid biomarkers, for $M$. tuberculosis, have been identified in archaeological samples for the first time, using the Coimbra Identified Skeletal Collection ${ }^{41,42}$ as a test case. The analytical procedure is designed to be a component of an integrated method designed to maximise the amount of information from a range of characteristic lipid biomarkers. When considering destructive analysis of irreplaceable material, such as archaeological samples, it is of paramount importance to preserve all extracted material in a stable form. Such extracts would then be available for future analysis, using increasingly sophisticated and sensitive procedures.

In the present procedure, efficient alkaline hydrolysis is followed by conversion of acidic components to stable PFB esters. Reproducible normal phase cartridge protocols then separate potential long-chain biomarkers into three main fractions for separate analysis. The first eluting non-hydroxylated PFB esters can be analysed by negative ion chemical ionisation gas chromatography mass spectrometry to record characteristic profiles of mycocerosic acids and any other potential biomarker acids, such as the mycolipenic acids detected in some of the present samples. The next fraction contains the hydroxylated mycolic acid PFB esters and a new procedure has been devised to analyse these by fluorescence HPLC of 1-pyrenebutyric acid ester derivatives. ${ }^{59}$ The final fraction from the cartridge separation contains the phthiocerol family which could be derivatised with PBA for fluorescence HPLC or a variety of other sensitive procedures.

Analysis of mycocerosic acid biomarkers, introduced in this study, adds another weapon in the search for information regarding ancient mycobacterial disease in archaeological materials. Lipid biomarkers, such as mycocerosic and mycolic acids, are particularly robust and are ideal in complementing detection of ancient DNA. ${ }^{11,29,59}$ In certain cases, mycolic acid biomarkers have been detected in archaeological samples which have been found negative for M. tuberculosis DNA. ${ }^{11}$

\section{Acknowledgements}

We are indebted to Dr. Malin Ridell (University of Gothenburg, Sweden) and the Central Veterinary Laboratory, Weybridge, UK, for providing standard mycobacterial cells. Thanks are also due to Drs. Laurie Cunliffe and Ian Podmore (University of Salford, UK) for their suggestions and their help with MS equipment.

Funding: Funding for JER came from a Wellcome Trust Bioarchaeology Prize Studentship. DEM was a Leverhulme Emeritus Fellow (2006-2008), also benefiting from a Wellcome Trust Research Leave Grant (2000-2001). Finally, we gratefully acknowledge The Leverhulme Trust for funding (Project Grant No. F/125/AK).

Competing interests: None declared.

Ethical approval: Not required.

\section{References}

1. World Health Organisation. Global Tuberculosis Control 2007: key findings. Geneva: World Health Organization, http://whqlibdoc.who.int/publications/ 2007/key_findings_eng.pdf; 2007.

2. Davies RPO, Tocque K, Bellis MA, Rimmington T, Davies PDO. Historical declines in tuberculosis in England and Wales: improving social conditions or natural selection? Vesalius 1999;5:25-9.

3. Grange JM, Gandy M, Farmer P, Zumla A. Historical declines in tuberculosis: nature, nurture and the biosocial model. Int J Tuberc Lung Dis 2001;5:208-12.

4. Ortner DJ. Identification of pathological conditions in human skeletal remains. London: Academic Press; 2003.
5. Roberts C, Lucy D, Manchester K. Inflammatory lesions of ribs: an analysis of the Terry Collection. Am J Phys Anthropol 1994;95:169-82.

6. Roberts CA, Buikstra JE. The bioarchaeology of tuberculosis. Gainsville: University Press of Florida; 2003.

7. Farer LS, Lowell LM, Meador MP. Extrapulmonary tuberculosis in the United States. Am J Epidemiol 1979;109:205-17.

8. Golden MP, Vikram HR. Extrapulmonary tuberculosis: an overview. Am Fam Physician 2005;72:1761-8.

9. Resnick D. Diagnosis of bone and joint disorders. Edinburgh: Saunders; 1995.

10. Kelley MA, El-Najjar MY. Natural variation and differential diagnosis of skeletal changes in tuberculosis. Am J Phys Anthropol 1980;52:153-67.

11. Gernaey AM, Minnikin DE, Copley MS, Dixon RA, Middleton JC, Roberts CA Mycolic acids and ancient DNA confirm an osteological diagnosis of tuberculosis. Tuberculosis 2001;81:259-65.

12. Spigelman M, Donoghue HD. Mycobacterium tuberculosis DNA in archaeological specimens. In: Pálfi G, Dutour O, Deák J, Hutás I, editors. Tuberculosis pas and present. Szeged: Golden Book Publisher Ltd., Tuberculosis Foundation; 1999. p. 353-60.

13. Donoghue HD, Spigelman M, Greenblatt CL, Lev-Maor G, Bar-Gal GK, Matheson C, et al. Tuberculosis: from prehistory to Robert Koch, as revealed by ancient DNA. Lancet Infect Dis 2004;4:584-92.

14. Zink AR, Reischl U, Wolf H, Nerlich AG. Molecular analysis of ancient microbial infections. FEMS Microbiol Lett 2002;213:141-7.

15. Donoghue HD. Molecular palaeopathology of human infectious disease. In: Pinhasi R, Mays S, editors. Advances in human palaeopathology. Chichester: Wiley; 2008. p. 147-76.

16. Spigelman M, Matheson C, Lev G, Greenblatt C, Donoghue HD. Confirmation of the presence of Mycobacterium tuberculosis complex specific DNA in three archaeological specimens. Int J Osteoarchaeol 2002;12:393-401.

17. Konomi N, Lebwohl E, Mowbray K, Tattersall I, Zhang D. Detection of mycobacterial DNA in Andean mummies. J Clin Microbiol 2002;40:4738-40.

18. Fusegawa H, Wang B-H, Sakurai K, Nagasawa K, Okauchi M, Nagakura K. Outbreak of tuberculosis in a 2000 year old Chinese population. Kansenshogaku Zasshi 2003;77:146-9.

19. Zink AR, Sola C, Reischl U, Grabner W, Rastogi N, Wolf H, et al. Characterization of Mycobacterium tuberculosis complex DNAs from Egyptian mummies by spoligotyping. J Clin Microbiol 2003;41:359-67.

20. Donoghue HD, Marcsik A, Matheson C, Vernon K, Nuorala E, Molto JE, et al. Coinfection of Mycobacterium tuberculosis and Mycobacterium leprae in human archaeological samples: a possible explanation for the historical decline of leprosy. Proc $R$ Soc B 2005;272:389-94.

21. Taylor GM, Young DB, Mays SA. Genotypic analysis of the earliest known prehistoric case of tuberculosis in Britain. J Clin Microbiol 2005;43:2236-40.

22. Taylor M, Murphy E, Hopkins R, Rutland P, Christov Y. First report of Mycobacterium bovis DNA in human remains from the Iron Age. Microbiology 2007; 153:1243-9.

23. Vijaya-Bhanu N, van Soolingen D, van Embden JDA, Seth P. Two Mycobacterium fortuitum strains isolated from pulmonary tuberculosis patients in Delhi harbour IS6110 homologue. Diagn Microbiol Infect Dis 2004;48:107-10.

24. Höss M, Jaruga P, Zastawny TH, Dizdaroglu M, Pääbo S. DNA damage and DNA sequence retrieval from ancient tissues. Nucleic Acids Res 1996;24:1304-7.

25. Hebsgaard MB, Phillips MJ, Willerslev E. Geologically ancient DNA: fact or artefact? Trends Microbiol 2005;13:212-20.

26. O'Rourke DH, Hayes MG, Carlyle SW. Ancient DNA studies in physical anthropology. Annu Rev Anthropol 2000;29:217-42.

27. Baron H, Hummel S, Herrmann B. Mycobacterium tuberculosis complex DNA in ancient human bones. J Archaeol Sci 1996;23:667-71.

28. Minnikin DE. Lipids: complex lipids, their chemistry, biosynthesis and roles. In: Ratledge C, Stanford J, editors. The biology of the mycobacteria, vol. 1. London: Academic Press; 1982. p. 95-185.

29. Donoghue HD, Spigelman M, Zias J, Gernaey-Child AM, Minnikin DE. Mycobacterium tuberculosis complex DNA in calcified pleura from remains 1400 years old. Lett Appl Microbiol 1998;27:265-9.

30. Gernaey AM, Minnikin DE, Copley MS, Power J, Ahmed AMS, Dixon RA, et al Detecting ancient tuberculosis. Internet Archaeol, http://interarch.ac.uk/journal/ issue5/gernaey_index.html, 1998;5.

31. Minnikin DE, Dobson G, Goodfellow M, Magnusson M, Ridell M. Distribution of some mycobacterial waxes based on the phthiocerol family. J Gen Microbio 1985:131:1375-81.

32. Daffé M, Lanéelle MA. Distribution of phthiocerol diester, phenolic mycosides and related compounds in mycobacteria. J Gen Microbiol 1988;134:2049-55.

33. Minnikin DE, Kremer L, Dover LG, Besra GS. The methyl-branched fortifications of Mycobacterium tuberculosis. Chem Biol 2002;9:545-53.

34. Draper P, Payne SN, Dobson G, Minnikin DE. Isolation of a characteristic phthiocerol dimycocerosate from Mycobacterium leprae. J Gen Microbiol 1983;129:859-63.

35. Hartmann S, Minnikin DE. Mycobacterial phenolic glycolipids. In: Tyman JHP editor. Surfactants in lipid chemistry: recent synthetic, physical and biodegradative studies. Cambridge: Royal Society of Chemistry; 1992. p. 135-58.

36. Minnikin DE, Bolton RC, Hartmann S, Besra GS, Jenkins PA, Mallet AI, et al. An integrated procedure for the direct detection of characteristic lipids in tuberculosis patients. Ann Soc Belge Med Trop 1993;73(Suppl. 1):13-24

37. Minnikin DE, Bolton RC, Dobson G, Mallet AI. Mass spectrometric analysis of multimethyl branched fatty acids and phthiocerols from clinically-significant mycobacteria. Proc Jpn Soc Med Mass Spectrom 1987;12:23-32. 
38. Minnikin DE, Besra GS, Bolton RC, Datta AK, Mallet AI, Sharif A, et al. Identification of the leprosy bacillus and related mycobacteria by analysis of mycocerosate profiles. Ann Soc Belge Med Trop 1993;73(Suppl. 1):25-34.

39. Larsson L, Mardh P, Odham G, Westerdahl G. Use of selected ion monitoring for detection of tuberculostearic and C32 mycocerosic acid in mycobacteria and in five-day-old cultures of sputum specimens from patients with pulmonary tuberculosis. Acta Pathol Microbiol Scand [B] 1981;89:245-51.

40. Alugupalli S, Sikka MK, Larsson L, White DC. Gas chromatography mass spectrometry methods for the analysis of mycocerosic acids present in Mycobacterium tuberculosis. J Microbiol Methods 1998;31:143-50.

41. Santos AL. TB files: new hospital data(1910-1936) on the Coimbra Identified Skeletal Collection. In: Pálfi G, Dutour O, Deák J, Hutás I, editors. Tuberculosis past and present. Szeged: Golden Book Publisher Ltd., Tuberculosis Foundation; 1999. p. 127-34.

42. Santos AL, Roberts CA. A picture of tuberculosis in young Portuguese people in the early 20th century: a multidisciplinary study of the skeletal and historical evidence. Am J Phys Anthropol 2001;115:38-49.

43. Mallet AI, Minnikin DE, Dobson G. Gas chromatography mass spectrometry of tert-butyldimethylsilyl ethers of phthiocerols and mycocerosic alcohols from Mycobacterium tuberculosis. Biomed Mass Spectrom 1984;11:79-86.

44. Gyllenhaal O, Ehrsson H. Determination of sulphonamides by electron capture gas chromatography. Preparation and properties of perfluoroacyl and pentafluorobenzyl derivatives. J Chromatogr 1975;107:327-33.

45. Minnikin DE, Dobson G, Hutchinson IG. Characterization of phthiocerol dimycocerosates from Mycobacterium tuberculosis. Biochim Biophys Acta 1983;753:445-9.

46. Iwata K, Smith BA, Santos E, Polsky B, Sordillo EM. Failure to implement respiratory isolation: why does it happen? Infect Control Hosp Epidemiol 2002;23:595-9.

47. Eamranond P, Jaramillo E. Tuberculosis in children: reassessing the need for improved diagnosis in global control strategies. Int $J$ Tuberc Lung Dis 2001;5:594-603.

48. Feja K, Saiman L. Tuberculosis in children. Clin Chest Med 2005;26:295-312.
49. Wang XC, Druffel ERM, Griffin S, Lee C, Kashgarian M. Radiocarbon studies of organic compound classes in plankton and sediment of the northeastern Pacific Ocean. Geochim Cosmochim Acta 1998;62:1365-78.

50. Staccioli G, McMillan NJ, Meli A, Bartolini G. Chemical characterisation of a 45 million year bark from geodetic hills fossil forest, Axel Heiberg Island, Canada. Wood Sci Technol 2002;36:419-27.

51. Camacho-Ibar VF, Aveytua-Alcázar L, Carriquiry JD. Fatty acid reactivities in sediment cores from the northern Gulf of California. Org Geochem 2003;34:425-39.

52. Haddad RI, Martens CS, Farrington JW. Quantifying early diagenesis of fatty acids in a rapidly accumulating coastal marine sediment. Org Geochem 1992;19:205-16.

53. Cowin SC, Weinbaum S, Zeng Y. A case for bone canaliculi as the anatomical site of strain generated potentials. J Biomech 1995;28:1281-97.

54. Harvey HR, Macko SA. Kinetics of phytoplankton decay during simulated sedimentation: changes in lipids under oxic and anoxic conditions. Org Geochem 1997;27:129-40.

55. Mayer LM. The inertness of being organic. Mar Chem 2004;92:135-40.

56. Tremblay L, Kohl SD, Rice JA, Gagné J-P. Effects of lipids on the sorption of hydrophobic organic compounds on geosorbents: a case study using phenanthrene. Chemosphere 2005;58:1609-20.

57. Guido L, Wiesenberg B, Schwarzbauer J, Schmidt MWI, Schwark L. Source and turnover of organic matter in agricultural soils derived from $n$-alkane $/ n$ carboxylic acid compositions and C-isotope signatures. Org Geochem 2004;35:1371-93.

58. Robinson S, Nicholson RA, Pollard AM, O'Connor TP. An evaluation of nitrogen porosimetry as a technique for predicting taphonomic durability in animal bone. J Archeol Sci 2003;30:391-403.

59. Hershkovitz I, Donoghue HD, Minnikin DE, Besra GS, Lee OY-C, Gernaey AM, et al. Detection and molecular characterization of 9000-year-old Mycobacterium tuberculosis from a Neolithic settlement in the Eastern Mediterranean. PLoS One 2008;3:e3426. doi:10.1371/journal.pone.0003426. 